\title{
Teknologi mesin pengering pakaian berbasis limbah tempurung kelapa untuk meningkatkan ekonomi bagi UKM yang bergerak dalam bidang laundry di Kecamatan Tampan Kota Pekanbaru
}

\author{
Antonius Surbakti*, Juandi Muhammad, Erman Taer, Ramondia Setiadi, \& Usman Malik \\ Universitas Riau \\ * antonius.pil2013@gmail.com
}

\begin{abstract}
Abstrak. Potensi sektor usaha ekonomi masyarakat pengusaha / UKM Laundry di Kecamatan Tampan Panam yang memiliki potensi usaha yang sangat potensial. Hal ini jelas menyimpan potensi sector usaha / UKM Laundry yang sangat besar. Sistim pengeringan pakaian yang dilakukan melalui metode pengeringan tradisional telah lama dipraktekkan oleh pengusaha UKM Laundry Secara khusus, kegiatan pengeringan pakaian telah sejak lama menjadi mata pencaharian bagi komunitas masyarakat UKM Laundry di Kecamatan Tampan Panam. Namun, pada umumnya, proses pengeringan pakaian melalui metode pengeringan dengan hanya mengandalkan sinar matahari belum optimal. Proses pengeringan pakaian oleh pengusaha laundry di Kecamatan tampan Panam masih dilakukan secara tradisonal, yaitu dijemur di bawah sinar matahari. Proses ini memakan waktu yang cukup lama, dibutuhkan waktu dalam pengeringan pakaian 2 sampai 4 hari dan itu pun tergantung adanya sinar matahari. Mesin pengering Pakaiaan yang dirancang memanfaatkan panas yang bersumber dari pembakaran limbah tempurung kelapa yang berfungsi sebagai kolektor panas. Sehingga proses pengeringan dapat berlangsung cepat, setiap saat dan tanpa tergantung sinar matahari. Pengendalian suhu pengeringan dilakukan dengan cara buka tutup saluran udara pada alat pengering Alat pengering ini terdiri dari kolektor surya, tungku pembakaran biomass, ruang pengering (box). Ruang pengering berfungsi sebagai tempat diletakkan pakaian-pakaian yang akan dikeringkan. Pengaliran panas yang bersumber dari pembakaran limbah Tempurung kelapa ke ruang pengering. Hasil pengeringan pakaian lebih baik dibandingkan dengan pengeringan secara tradisional. Teknologi pengeringan berbasis limbah tempurung kelapa untuk mengeringkan pakaian akan diaplikasikan di masyarakat UKM Laundry di Kecamatan tampan Panam, Pekanbaru yang menjadai mata pencarian sebagian UKM di Kecamatan Tampan Kota Pekanbaru.
\end{abstract}

Kata kunci: biomassa, pengeringan, teknologi

\begin{abstract}
The potential of the laundry sector, the entrepreneur community / UKM Laundry in Tampan District, which has very potential business potential. This clearly saves the huge potential of the Laundry / UKM business sector. The clothes drying system, which is carried out through the traditional drying method, has long been practised by Laundry UKM entrepreneurs. In particular, the clothes drying activity has long been a source of livelihood for the Laundry UKM community in Panam District. However, in general, the process of drying clothes through a drying method that relies solely on sunlight is not optimal. The process of drying clothes by laundry entrepreneurs in the Tampan District is still done traditionally, namely drying in the sun. This process takes a long time, it takes 2 to 4 days to dry clothes and it also depends on the presence of sunlight. The drying machine is designed to utilize heat from burning coconut shell waste which functions as a heat collector. So that the drying process can take place quickly, at any time and without depending on the sun. Control of the drying temperature is done by opening and closing the air ducts in the dryer. This dryer consists of a solar collector, biomass burning furnace, and drying room (box). The drying room functions as a place for clothes to be dried. The flow of heat from burning coconut shell waste to the drying chamber. The result of drying clothes is better than traditional drying. The drying technology based on coconut shell waste to dry clothes will be applied in the Laundry UKM community in Tampan District, Pekanbaru which is the livelihood of some UKM in Tampan District, Pekanbaru City.
\end{abstract}

Keywords: biomass, drying, technology

To cite this article: Surbakti, A., J. Muhammad., E. Taer., R. Setiadi., \& U. Malik. 2020. Teknologi mesin pengering pakaian berbasis limbah tempurung kelapa untuk meningkatkan ekonomi bagi UKM yang bergerak dalam bidang laundry di Kecamatan Tampan Kota Pekanbaru. Unri Conference Series: Community Engagement 2: 550-558. https://doi.org/10.31258/unricsce.2.550-558

Peer-review under responsibility of the organizing committee of Seminar Nasional Pemberdayaan Masyarakat 2020 


\section{PENDAHULUAN}

Lokasi kegiatan pengabdian bertempat di Kelurahan Sialang Munggu, Kecamatan Tampan, Kota Pekanbaru. Kelurahan Sialang Munggu merupakan kelurahan pemekaran antara Kelurahan Sidomulyo Barat dan Kelurahan Tuah Karya (Pasal 18 Perda Kota Pekanbaru Nomor 4 tahun 2016 tentang pembentukan Kelurahan Kota Pekanbaru). Kelurahan ini terdiri atas 31 RW dan 127 RT. Jumlah penduduk kecamatan ini adalah sebesar 39.305 jiwa dengan jumlah perincian laki-laki sebanyak 19.534 jiwa dan perempuan sebanyak 19.771 jiwa. Jumlah penduduk tersebut terbagi dalam Kepala Keluarga sebanyak 10.560 KK.

Luas wilayah kelurahan ini $\pm 3,5 \mathrm{~km} 2$. Ditinjau dari letak geografisnya (Perda Kota Pekanbaru Nomor 4 Tahun 2016), Sebelah Utara Kelurahan Sialang Munggu berbatasan langsung dengan Jalan Soebrantas (Kelurahan Simpang Baru dan Kelurahan Tobek Godang), Sebelah Selatan berbatas dengan Pilar Batas Kabupaten Kampar, Sebelah Barat berbatas dengan Jalan Suka Karya (Kelurahan Tuah Karya), Sebelah Timur berbatas dengan Jalan Purwodadi dan Jalan Gelora (Kelurahan Sidomulyo Barat).

Pekerjaan setiap kepala keluarga di Kelurahan Sialang Munggu antara lain bertani, berkebun, berternak, wirausaha, PNS dan lain-lain. Kelurahan ini banyak terdapat industri-industri rumahan (home industry), diantaranya seperti rumah potong yang menghasilkan olahan seperti kerupuk jangek, olahan rendang teri hasil karya ibu-ibu, serta UKM-UKM yang berguna untuk peningkatan ekonomi masyarakat seperti UKM yang bergerak dalam bidang Laundry. Semua menjadi produk andalan dari kelurahan ini. Tidak heran kalau mayoritas penduduk kelurahan ini bermata pencaharian sebagai pedagang.

Kecamatan Tampan merupakan salah satu wilayah yang memiliki potensi UKM Laundry yang sangat potensial di Pekanbaru. Hal ini jelas menjadi sumber ekonomi yang sangat besar. Selain menghasilkan UKM muda, UKM di Kecamatan Tampan panam juga membuka lapangan kerja bagi mahasiswa. UKM Laundry menjadi salah satu objek usaha di Panam sebagai sentra UKM Laundry. Sentra UKM laundry dan sentra UKM di Panam.

Usaha laundry bemilai ekonomi penting di Panam ini. Adapun UKM komoditas Laundry di Panam ini diklasifikasikan menjadi dua bentuk, yaitu UKM Kecil dan UKM menengah. UKM ini mempunyai sifat khusus, yaitu modal sedikit. Sifat khusus ini disamping menyebabkan UKM tersebut mudah berkembang tetapi memerlukan penanganan khusus pada saat hari hujan, dan juga harus memerlukan lapangan yang luas untuk mengeringkan pakaian. Oleh karena itu sentuhan teknologi sangat diperlukan dan merupakan ujung tombak dalam pengembangan sector UKM Laundry. Solusi untuk mengatasi UKM Laundry ini yang memiliki sifat khusus tersebut adalah dengan melakukan kegiatan berkelanjutan (sustainable development) untuk meningkatkan ekonomi masyarakat UKM Laundry melalui teknologi energi biomassa limbah tempurung kelapa yang ramah lingkungan dan berkelanjutan.

Berdasarkan informasi dari UKM Laundry. Ada beberapa kelemahan sector usaha Laundry yang diterapkan oleh UKM yaitu system masih tradisional sehingga menghadapi beberapa kelemahan sebagai berikut: (1). waktu pengeringan sangat lama yaitu 1 - 2 hari, sehingga dapat mengurangi pendapatan. (2). Masalah polusi udara yang dapat membuat pakaian beraroma tak sedap. (3). Kesulitan ketika hujan tidak dapat menjemur pakaian. Akibatnya dapat menurunkan pendapatan (Hasil wawancara Tim pada tgl. 1 Maret 2019).

\section{Masalah}

Berdasarkan analisis situasi diatas maka permasalahan yang ada pada masyarakat UKM di Kecamatan Tampan adalah:

a. Bahwa UKM Laundry di Kecamatan Tampan, yang bergerak dalam usaha Laundry usaha telah mengalami kesulitan untuk mengeringkan Pakaian karena ketika cuaca tidak cerah dan musim hujan tidak dapat menjemur pakaian.

b. Masyarakat UKM di Kecamatan Tampan yang bergerak dalam usaha Laundry telah mengalami kesulitan untuk menjemur pakaian karena dapat terkontaminasi dengan polusi atau kotoran.

c. Masyarakat UKM di Kecamatan Tampan yang bergerak dalam usaha Laundry telah mengalami kesulitan untuk menjemur pakaian, karena system tradisional itu memerlukan waktu yang sangat lama untuk mengeringkan pakaian, apa lagi jenis Levis bisa memerlukan waktu 1-2 hari. 


\section{METODE PENERAPAN}

\section{Lokasi Kegiatan Pengabdian}

Lokasi Kegiatan pengabdian ini berada di Kelurahan Sialangmunggu Kecamatan Tampan Kota Pekanbaru, Provinsi Riau.

\section{Waktu Kegiatan}

Kegiatan ini bersamaan dengan KUKERTA terintegrasi dengan durasi kegiatan sebanyak 30 kali pertemuan mencakup kedalam semua kegiatan mahasiswa yang KUKERTA di Kelurahan Sialangmunggu Kecamatan Tampan Kota Pekanbaru, Provinsi Riau Kegiatan pengabdian ini dilakukan dengan menggunakan metode praktek/penyuluhan yaitu dengan membuat alat pengering menggunakan energi biomassa dari limbah tempurung kelapa khususnya yang berkaitan dengan permasalahan untuk meningkatkan kualitas pengeringan pakaian basah.

\section{Alat dan Bahan Penelitian}

\begin{tabular}{lll}
\hline No & Bahan & Fungsi \\
\hline 1. & Kayu broti & Sebagai penyangga kolektor dan kerangka alat pengering \\
2. & Plat seng & Sebagai penghantar panas \\
3. & Thermometer mercuri & Alat pengukur suhu ruangan pengering dan suhu sekitar \\
4. & Paku pines & Sebagai perekat plat seng dan tripek \\
5. & Stopwatch & Sebagai alat pengukur waktu \\
6. & pipa seng & Sebagai cerobong \\
7. & Drum & Sebagai ruang energi biomassa \\
8. & Kawat & Sebagai rak penggantung pakaian basah dalam penelitian \\
9. & Pakaian basah & Sebagai bahan penelitian \\
10. & Timbangan & Mengukur massa pakaian basah dan massa bahan bakar \\
11. & Cat hitam & Sebagai pelapis seng pada kolektor \\
12. & Triplek & Sebagai isolator \\
13. & Paku & Sebagai penghubung antara kayu \\
14. & Rookwool & Sebagai peredam panas \\
15. & Paralon & Sebagai cerobong pembuangan asap pembakaran \\
16. & Tempurung kelapa & Sebagai bahan bakar \\
17. & Batu kerikil & Sebagai absorben \\
\hline
\end{tabular}

\section{Alat Pengering Energi Biomassa}

Alat pengering ini dibuat berbentuk persegi panjang dengan ukuran panjang kali lebar, $90 \mathrm{~cm}$ x $45 \mathrm{~cm}$ dan tinggi $170 \mathrm{~cm}$. Alat pengering dibuat berdindingkan triplek dan pada bagian dalam dilapisi seng dengan ketebalan 0,7 mm, bagian permukaaan seng diberi cat berwarna hitam. Setelah ukuran kayu sudah sesuai dengan ukuran yang dikehendaki hubungkan masing-masing sisi kayu dengan sisi kayu yang lainnya menggunakan paku.

\section{Ruang Pengering}

Ruangan pengering diisi dengan 1 penyangga atau 1 tempat penggantung pakaian, $15 \mathrm{~cm}$ jarak dari tempat penggantung pakaian keatap ruang pengering, dan $100 \mathrm{~cm}$ dari ruang energi biomassa . Pada dasar ruangan pengering diisi dengan drum yang berukuran $50 \mathrm{~cm}$ dan diameter $40 \mathrm{~cm}$. Drum ini berfungsi untuk mengolah limbah tempurung kelapa menjadi energi biomassa yang menimbulkan panas yang dapat mengeringkan pakaian basah. Pada bagian atas ruangan pengering ini diberi cerobong untuk jalan udara keluar dari dalam ruangan pengering. Gambar ruangan pengering ditunjukan pada Gambar 1. 


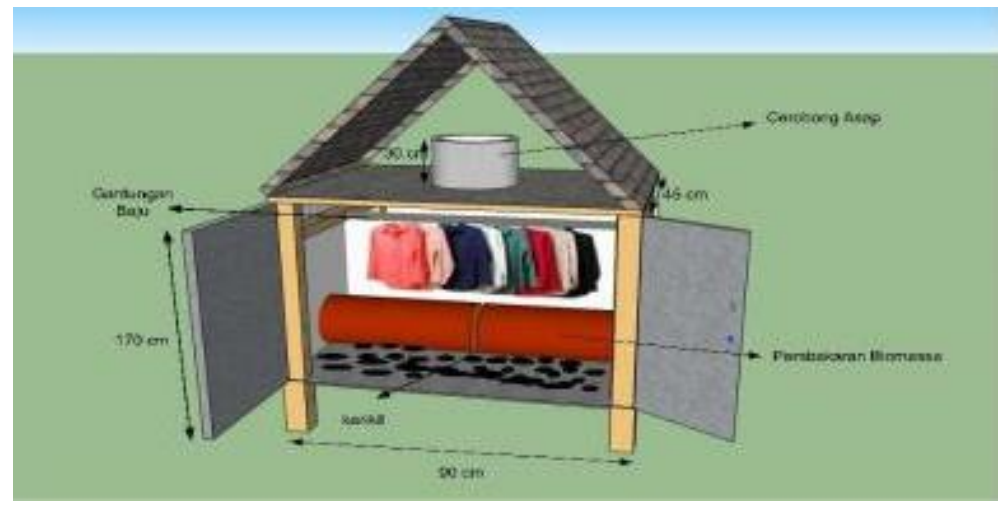

Gambar 1. Desain Alat Pengering Energi Biomasssa dari limbah tempurung kelapa

\section{Penyangga gantungan baju}

Gantungan baju pakaian basah yang ada di dalam ruangan pengering ini mempunyai panjang $90 \mathrm{~cm}$ dan ketebalan $3 \mathrm{~cm}$. Rak pengering dibuat dari kawat besi dengan diletakan didalam ruang pengering tepatnya diatas drum tempat pembakaran biomassa. Bagan dari rak pengering ditunjukan pada Gambar 2. Rak pengering yang didesain ini yaitu agar gantungan baju bisa diletakkan di rak tersebut.

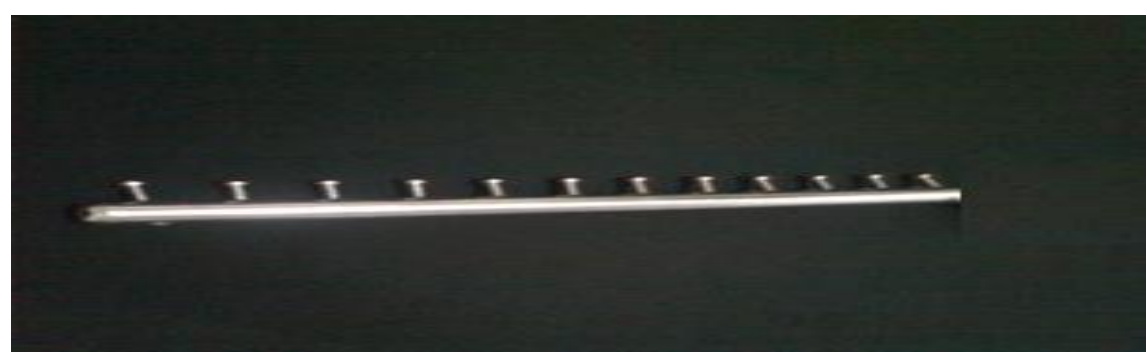

Gambar 2. Gantungan baju pakaian basah

\section{Cerobong}

Cerobong alat pengering berbentuk silinder dari seng yang mempunyai diameter $10 \mathrm{~cm}$ dan tingginya $30 \mathrm{~cm}$ dan tebalnya $0,7 \mathrm{~mm}$. Cerobong ini berfungsi untuk menyeimbangkan suhu dalam ruang pengering, sehingga suhu didalam ruang pengering sekitar $57 \mathrm{oc}-68 \mathrm{oc}$.

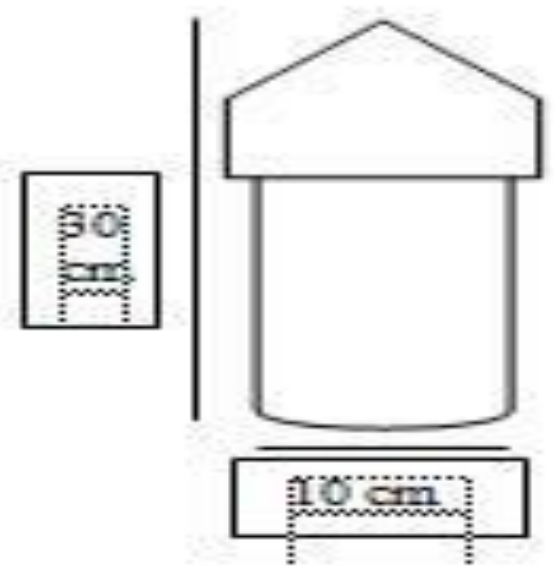

Gambar 3. Cerobong 


\section{HASIL DAN KETERCAPAIAN SASARAN}

\section{Gambaran umum masyarakat sasaran}

Pekerjaan setiap kepala keluarga di Kelurahan Sialang Munggu antara lain bertani, berkebun, berternak, wirausaha, PNS dan lain-lain. Kelurahan ini banyak terdapat industri-industri rumahan (home industry), diantaranya seperti rumah potong yang menghasilkan olahan seperti kerupuk jangek, olahan rendang teri hasil karya ibu-ibu, serta UKM-UKM yang berguna untuk peningkatan ekonomi masyarakat seperti UKM yang bergerak dalam bidang Laundry. Semua menjadi produk andalan dari kelurahan ini. Tidak heran kalau mayoritas penduduk kelurahan ini bermata pencaharian sebagai pedagang.

Salah satu alasan kelompok kami memilih Kelurahan Sialang Munggu menjadi tempat penelitian adalah karena UKM Laundry merupakan UKM favorit yang ada di Kelurahan Sialang Munggu, dibuktikan dengan banyaknya jumlah UKM Laundry yang dapat dijumpai di kelurahan ini. Tujuan dari penelitian ini adalah untuk meningkatkan ekonomi UKM Laundry. Karena alat pengering yang kami temukan hanya bermodalkan tempurung kelapa yang tidak sulit untuk ditemukan. Sehingga dapat menekan modal menjadi lebih murah daripada menggunakan listrik dan dapat menghemat waktu menjemur karena panas yang dihasilkan mesin ini bisa mencapai $80^{\circ} \mathrm{C}$ dalam waktu hanya $1 \mathrm{jam}$. Sehingga para pemilik UKM laundry dapat memperoleh untung yang lebih banyak.

\section{Potensi pengembangan (pemberdayaan) masyarakat}

Dengan menjamurnya usaha laundry maka kebutuhan energi yang dibutuhkan semakin meningkat. Sumber energi umumnya yang digunakan adalah energi listrik dan energi bahan bakar gas (LPG). Nilai investasi mesin pengering cukup mahal dan energinya harus dibeli sehingga biaya produksi laundry menjadi mahal. Melihat potensi energi dari hasil pembakaran tempurung kelapa, potensi ini sangat berpeluang untuk digunakan menjadi sumber energi pada pengering pakaian. Manfaat lain yang diperoleh adalah secara umum dapat menjaga keberlangsungan energi.

\section{Solusi pengembangan (pemberdayaan) masyarakat}

Dari hasil penelitian yang telah dilakukan, dapat ditarik kesimpulan bahwa teknologi mesin pengering pakaian berbasis limbah tempurung kelapa merupakan suatu alat yang sangat dibutuhkan oleh masyarakat sebagai alternatif atau solusi yang baik untuk dipakai di UKM Laundry, karena saat musim penghujan pun alat ini tetap bisa dipakai untuk mengeringkan pakaian dan tidak membutuhkan waktu yang lama untuk membuat kain yang basah menjadi kering.

\section{Luaran utama kegiatan}

Biomassa dapat digunakan sebagai sumber energy (Asnawi. 2002). Teknologi diperlukan untuk dapat memanfaatkan energy guna keperluan manusia (Irawan B. 2001. Luaran utama kegiatan pengabdian ini adalah menghasilkan teknologi pengeringan pakaian basah berbasis biomassa, seperti ditunjukkan pada Gambar 4 .

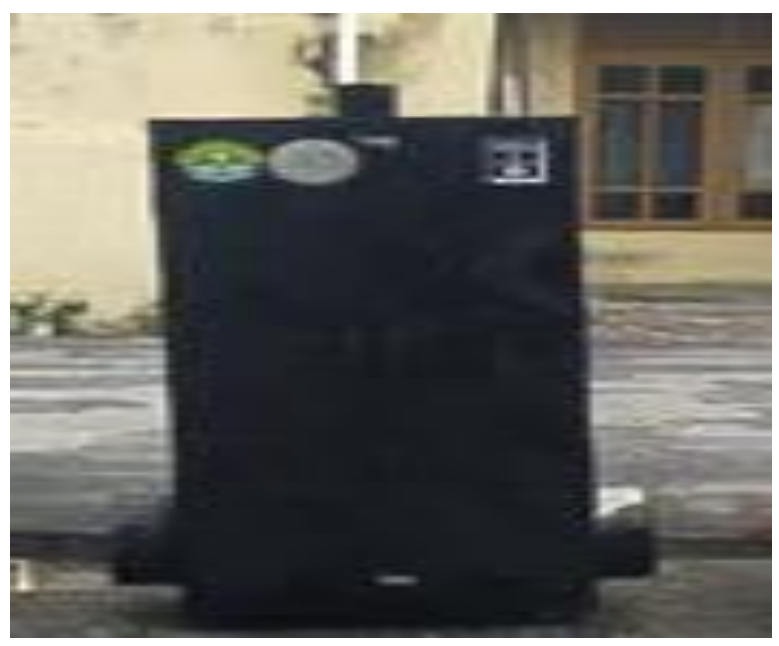

Gambar 4. Luaran utama pengabdian Mesin Pengering Pakaian Basah 
Gambar 4 menunjukkan luaran utama kegiatan pengabdian, yaitu berupa alat teknologi pengering pakaian basah berbasis energy biomassa. Pengurangan kadar air pakaian basah pada alat pengering sangat besar, pengurangan kadar air pakaian basah mancapai $2.439 \%$ pada waktu 60 menit (Gambar 5).

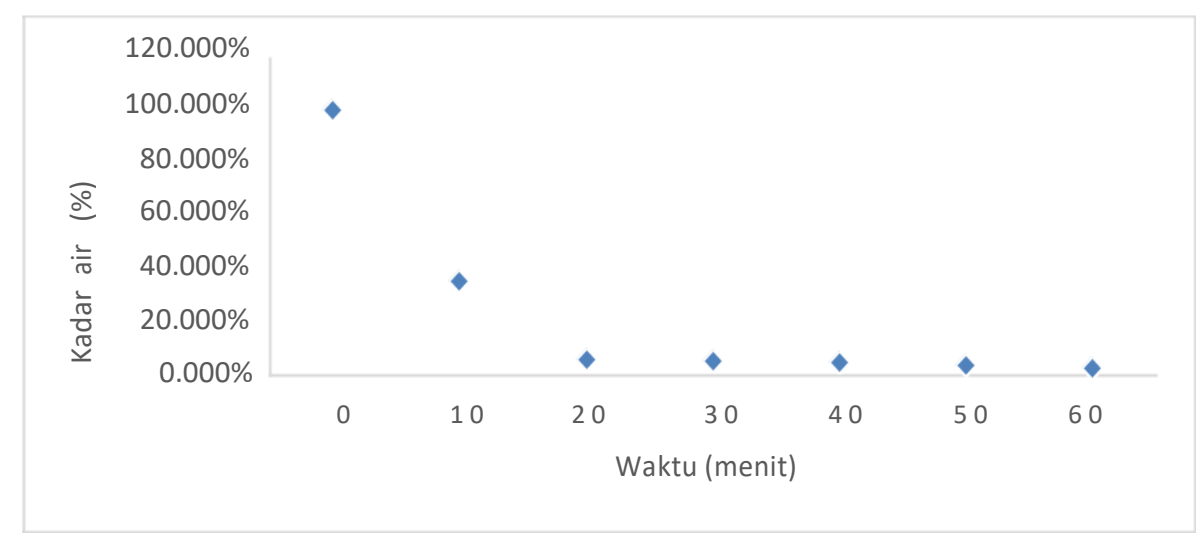

Gambar 5. Grafik hubungan antara kadar air dari pakaian basah terhadap waktu

Gambar 6, tim Kukerta terintegrasi telah melakukan sosialisasi teknologi pengering pakaian basah berbasis biomassa. Alat teknologi ini memiliki efesiensi kerja yang baik, hanya dalam tempo waktu 60 menit telah berhasil mengeringkan pakaian dengan baik.

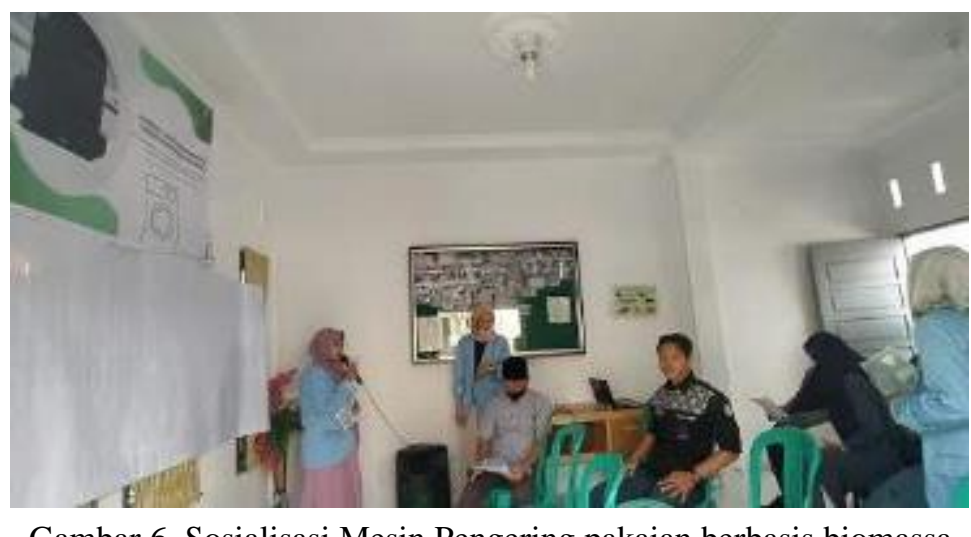

Gambar 6. Sosialisasi Mesin Pengering pakaian berbasis biomassa

\section{Keunggulan dan kelemahan kegiatan}

Adapun keunggulan kegiatan pengabdian ini terletak pada efesiensi waktu dan peningkatan manajemen produksi. Secara efesiensi waktu UKM Laundry hanya memerlukan waktu 60 menit untuk mengeringkan pakaian basah, dan peningkatan manajemen produksi ditandai dengan tidak perlu lagi UKM Laundry melakukan pengawasan, artinya terhindar dari gangguan hujan, tentu hal ini akan dapat meningkatkan pendapatan. (Gambar 7).

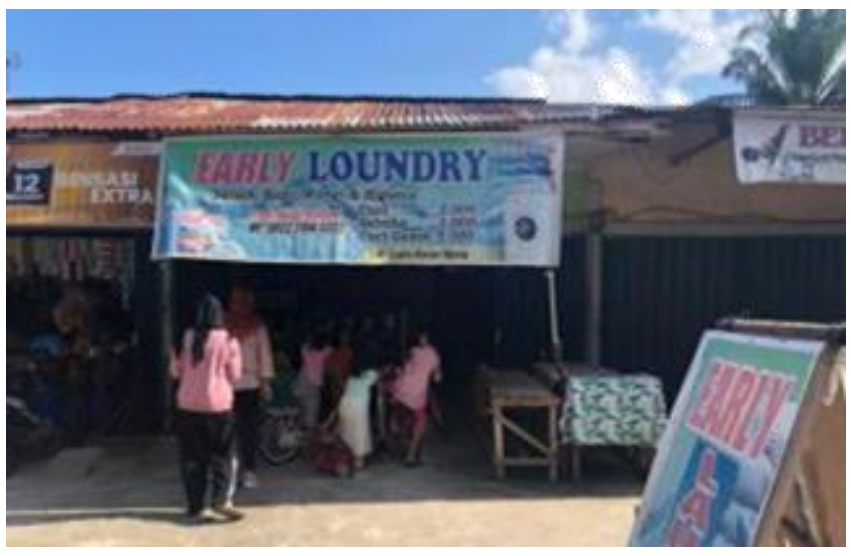

Gambar 7. Salah satu Sosialisasi ke UKM Laundry 
Hasil kegiatan pengabdian ini menunjukkan antusias yang tinggi dari masyarakat dimana produksi dapat diperoleh hanya dalam waktu 1 jam dengan temperature dalam ruang pengering mencapai $40 \mathrm{~s} / \mathrm{d} 65$ derajat Celsius (Gambar 8).

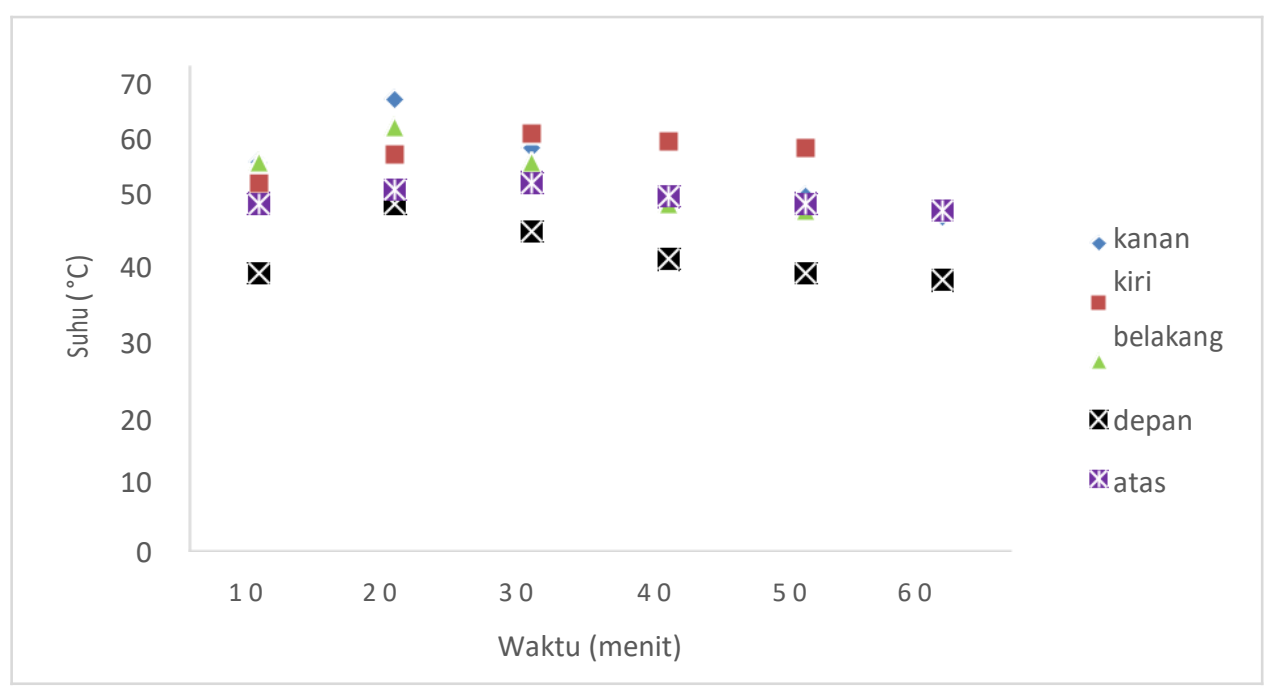

Gambar 8. Grafik suhu di dalam mesin pengering terhadap waktu dengan bahan bakar limbah biomassa tempurung kelapa

\section{Tingkat Kepuasan pelaksanaan kegiatan}

Tingkat Kepuasan pelaksanaan kegiatan pengabdian ini terlihat pada Respon masyarakat desa mengenai penyuluhan ini sangat bagus. Banyak masyarakat yang berbondong-bondong ingin mencoba alat. Selain itu juga, masyarakat juga kooperatif saat penyuluhan. Antusias warga terhadap kegiatan pengabdian yang dilakukan, dimana warga yang sedang berjalanpun singgah dan bertanya tentang maksud kegiatan ini, karena tidak semua warga yang diundang dalam kegiatan ini, yang di undang hyanyalah warga yang berprofesi UKM Laundry.

Tingkat kepuasan warga juga ditandai dengan ucapan terima kasih yang disampaikan warga saat selesai kegiatan sosialisasi mesin pengering pakaian berbasis biomassa., seperti ditunjukkan dalam Gambar 9.

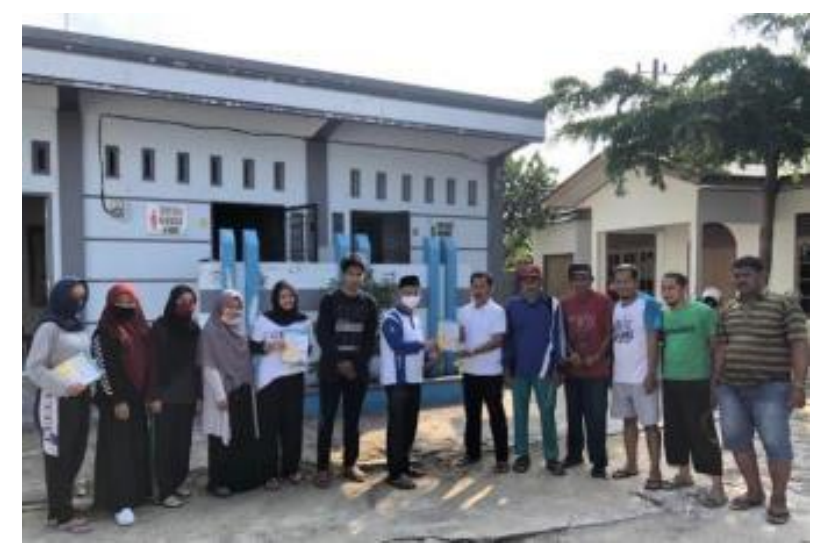

Gambar 9. Ungkapan antusias masyarakat terhadap kegiatan pengabdian

Kegiatan pengabdian ini terintegrasi dengan KUKERTA mahasiswa UNRI tahun 2020 seperti ditunjukkan dalam Tabel 1. 
Tabel 1. Mahasiswa Kukerta yang terintegrasi dalam kegiatan pengabdian

\begin{tabular}{lc} 
Nama & NIM \\
\hline Muklisin & 1707111524 \\
Husna Iffah M. & 1707114436 \\
Rafli Pratama & 1706122537 \\
Retno Esti Hidayanti & 1703110260 \\
Nur Ahmad Adriansyah & 1703110977 \\
Tesya Febiola & 1703121808 \\
Uswatun Hasanah & 1703110678 \\
Anisya Puja & 1703113479 \\
Adinda Chandra Fadhilla & 1701110086 \\
Fierera Wihesa & 1701110240 \\
\hline
\end{tabular}

Kegiatan ini dilaksanakan di Kelurahan Sialangmunggu Kecamatan Tampan Kota Pekanbaru selama 30 kali pertemuan. Berdasarkan dari tema pengabdian, Kelompok Kukerta ini melaksanakan Penyuluhan tentang mesin pengering pakaian basah berbasis Energi Biomassa yang Ramah Lingkungan, Penyuluhan Penerapan Energi Biomassa yang Ramah Lingkungan untuk Meningatkan Ekonomi Masyarakat UKM Laundry, Penerapan Alat Mesin Pengeringan dan Penyuluhan Pemanfaatan Energi Biomassa yang Ramah Lingkungan untuk Pengeringan pakaian basah. Masyarakat sangat antusias selama kegiatan.

Teknologi dapat digunakan sebagai upaya untuk meningkatkan ekonomi masyarakat (Alma, 2000). Selain adanya penyuluhan tersebut, alat yang menjadi alat bantu pengeringan pakaian ini diberikan kepada masyarakat sebagai upaya peningkatan ekonomi.

Tanda keberhasilan dari pelaksanaan kegiatan pengabdian ini ditandai dengan foto bersama sebagai tanda bahwa kegiatan pengabdian ini telah sukses dilaksanakan di Kelurahan Sialangmunggu Kecamatan Tampan Kota Pekanbaru, seperti ditunjukkan dalam Gambar 10.

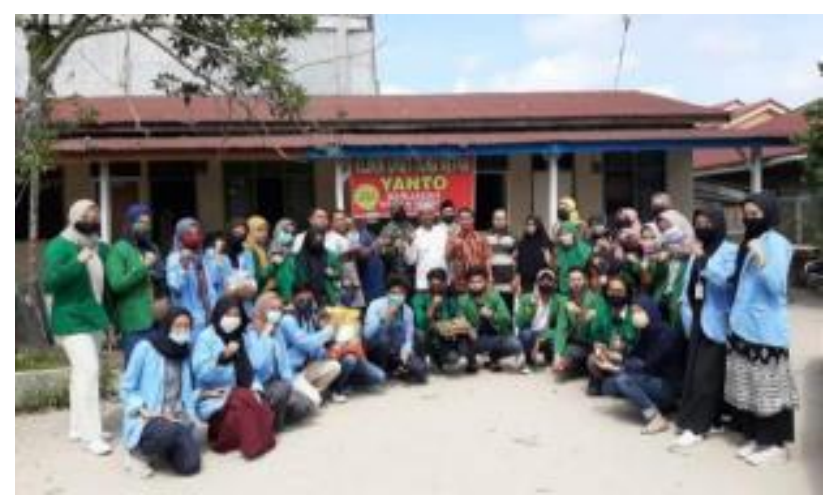

Gambar 8. Foto bersama seusai kegiatan pengabdian

\section{KESIMPULAN}

Berdasarkan hasil pelaksanaan pengabdian pada masyarakat yang telah dilakukan serta analisa, maka dapat diambil kesimpulan yaitu telah berhasil diterapkan teknologi mesin pengeringan pakaian berbasis biomassa di Kelurahan Sialang Munggu, Kecamatan Tampan, Kota Pekanbaru. Provinsi Riau. Bahwa masyarakat sangat antusias dalam kegiatan tersebut, dimana pengeringan pakaian basah dapat diperoleh hanya dalam waktu 1 jam dengan temperature dalam ruang pengering mencapai $40 \mathrm{~s} / \mathrm{d} 65$ derajat Celsius.

Rekomendasi yang diberikan agar masyarakat dapat secara konsisten menerapkan ilmu yang telah diajarkan yaitu penggunaan teknologi mesin pengeringan pakaian berbasis biomassa untuk UKM Laundry. 


\section{UCAPAN TERIMA KASIH}

Ucapan terima kasih kepada LPPM UR yang telah memberi bantuan dana dan ucapan terimaksih kepada mahasiswa Kukerta yang telah membantu dalam praktek lapangan bersama masyarakat.

\section{DAFTAR PUSTAKA}

Aman, W. P., Abadi Jading, dan Mathelda K. Roreng. 2015. Prototipe Alat Pengering Tipe Rotari (Rotary Dryer) bersumber Panas Biomassa Untuk Industri Pengolahan Pati Sagu di Papua.Universitas Negeri Papua.

Bargumono, H .M dan Suyadi Wongsowijaya. 2013. 9 Umbi Utama Sebagai Pangan Alternatif Nasional. Yogyakarta: Leutika prio.

Barret, M. D. dan Damardjati, S. D. 1984. Peningkatan Mutu Hasil Ubi Kayu di Indonesia.Jakarta.

Buchori, L. 2004. Perpindahan Panas Bagian 1. Universitas Diponegoro: Semarang.

Jamilatun.S. 2008.Sifat-Sifat Penyalaan dan Pembakaran Briket Biomassa, Briket Batubara dan Arang Kayu. Yogyakarta. Jurnal Rekayasa Proses, 2(2).

Kadir, A. 1995. Energi: Sumber Daya, Inovasi, Tenaga Listrik, Potensi Ekonomi. Cet. 1. Edisi kedua/revisi. Jakarta: Universitas Indonesia (UI-Press).

Koswara, S. 2013. Teknologi Pengolahan Umbi-Umbian Bagian 6: Pengolahan Singkong. Universitas Pertanian Bogor.

Mikheyev, M. 1986. Fundamentals of Heat Transfer. John Willey \& Sons Inc: New York.

Najib, L., dan Sudjud Darsopuspito. 2012.Karakterisasi Proses Gasifikasi Biomassa Tempurung Kelapa Sistem Downdraft Kontinyu dengan Variasi Perbandingan Udara Bahan Bakar (AFR) dan Ukuran Biomassa. Surabaya. Jurnal Teknik POMITS, 1(1), 1-4.

Nugroho, J. W. K., Destiani Supeno, dan Nursigit Bintoro. 2013. Pengeringan Krupuk Singkong Menggunakan Pengering Tipe Rak. Lembaga Penelitian Universitas Lampung.

Pari, G., Mahfudin, dan Jalali. 2012. Teknologi Pembuatan Arang, Briket Arang dan Arang Aktif Serta Pemanfaatannya. Gelar Teknologi Tepat Guna. Semarang.

Palungkun, R. 1999. Aneka Produk Olahan Kelapa.Bogor: Penebar Swadaya.

Sears, F. W. dan Mark W. Zemansky. 1962. Fisika Untuk Universitas 1: Mekanika, Panas, dan Bunyi. Jakarta: Yayasan Dana Buku Indonesia.

Silalahi. 2000. Penelitian Pembuatan Briket Kayu dari Serbuk Gergajian Kayu. Bogor: Hasil Penelitian Industri DEPERINDAG.

Suhardiyono, L. 1995. Tanaman Kelapa: Budidaya dan Pemanfaatannya. Yogyakarta: Kanisius.

Sumarno. 2011. Studi Experimental Alat Pengering Krupuk Udang Bentuk Limas Kapasitas 25 KG per Proses Dengan Menggunakan Energi Surya dan Energi Biomassa Arang Kayu. Politeknik Negeri Semarang.

Suriadi, I. G. A. K. dan Made Ricki Murti. 2011. Kesetimbangan Energi Termal dan Efesiensi Transient Pengering Aliran Alami Memanfaatkan Kombinasi Dua Energi.Universitas Udayana.

Syaiful, M., dan Hargono. 2009. Profil Suhu pada Proses Pengeringan Produk Pertanian dengan Simulasi Fluid Dynamics (CFD). Universitas Bengkulu. Reaktor, 12(3), 195-202.

Tipler, P. A. 1998. Fisika Untuk Sains dan Teknik. Edisi Ketiga.Jilid 1. Jakarta: Erlangga.

Nadia Lula. 2006. Jangek. Jurnal Matematika, Sains, dan Teknologi, 7(2), 111-120

Marwiyah. 2006. Dasar Busana, Paparan Kuliah, TJP UNNES.

Mohamad Ansori, Textile, Uniforms and Tailors, Jakarta: Diakses pada tanggal 08 november 2011.

http://www.dekkatama.blogspot.com

Muchamad Fauzi. 2009. Metode Penelitian Kuantitatif, Semarang: Walisongo.

Rodia Syamwil dan Adhi Kusumastuti. 2009. Pengetahuan Tekstil Untuk Tata Busana, Paparan Kuliah, TJP UNNES. 